ISSN 2616-7328 (Online), ISSN 2409-904X (Print)

Kitaêznavčì doslìdžennâ, 2019, No. 1, pp. 20-31

doi: https://doi.org/10.15407/chinesest2019.01.020

UDC: 930.1(510):001.32(477)-051]“1936/1938”

\title{
UKRANIAN ORIENTALIST SOCIETY IN HARBIN (1936-1938): CHINESE STUDIES
}

\author{
R. Lakh \\ Master's degree \\ The Ivan Franko National University of Lviv, \\ the Chair of Modern and Contemporary History of Foreign Countries \\ 1 Universytetska Str., Lviv, 79000, Ukraine \\ roman11lah@gmail.com
}

The present article outlines the activities of the Ukrainian Orientalists Society in the Far East. This society was founded in early 1936 and stopped its activities in early 1938, as there was no information about the organization after this year. The most active members of UOS were: Fedir Danilenko (president), Boris Vobliy (secretary), Dmitry Barchenko, Vasyl Odynets, Valentina Korda-Korotenko.

For the first time the article introduced a collection called "Far East" published in 1936 and it was declared as non-periodic. In particular, there were published the examples of traditional Chinese poetry translated by D. Barchenko. F. Danilenko completed the translation of the story written by Pu Songling from the cycle "Strange stories from a Chinese studio". The plot of the play "The Goddess of the Moon" included in this collection, depicts the traditional Taoist universe. V. Odinets in "Kytay or China" presented the history and etymology of the names of the Chinese Civilization. The "Report on the work of the Ukrainian National Colony in Manchukuo" published in 1937 by "Record Press" was the last source where the UOS was mentioned. At the end of the book there is a list of the reports completed by members of the Ukrainian Orientalists Society from December 1936 to March 1937: T. Gordeyev "Agricultural conditions in Manchuria", V. Odinets "Van-Dao", V. Korotenko "Love of the Chinese", V. Odinets "Cult of the Ancestors of the Chinese, F. Danilenko "The Goddess of Mercy" and "Confucius and Its Science", V. Odinets "Pioneers of Ukrainian Oriental Studies" and "Knowing the East". In Ukrainian science on the Chinese literature these translations do not have any analogues, so they are of special interest. In general, this publication will trace the history of the formation of Ukrainian orientalism in the territory of China.

Keywords: Ukrainian Orientalist Society, Sinology, Ukrainian Orientalists, UkrainianChinese relations, Harbin

\section{ТОВАРИСТВО УКРАЇНСЬКИХ ОРІЕНТАЛІСТІВ У ХАРБІНІ (1936-1938 рp.): КИТАЄЗНАВЧІ СТУДІЇ}

\author{
P. A. Лax
}

\section{Вступ}

Заради відродження та подальшого розвитку сходознавства в незалежній Україні потрібно докладно вивчити історію формування цієї наукової галузі,

C 2019 R. Lakh; Published by the A. Yu. Krymskyi Institute of Oriental Studies, NAS of Ukraine and the Ukrainian Association of Sinologists on behalf of The Chinese Studies. This is an Open Access article distributed under the terms of the Creative Commons Attribution License (https://creativecommons.org/licenses/by-nc-nd/4.0/). 
тим паче, що зараз зростає увага до особистості та іiі ролі в науці, тому все більше фахівців звертаються до біоісторіографії, яка стала однією $з$ пріоритетних гілок сучасної історичної науки. Товариство українських орієнталістів стало справжнім феноменом сходознавства, яке змогло творити справжню науку за межами своєї Батьківщини, зберігаючи традиції саме української орієнталістики. Вважалося, що з приходом радянської влади на територію України, сходознавство або було знищено, або спрямоване в соціально-економічне русло, залишивши поза увагою такі важливі галузі науки, як філософія та культура. Однак члени ТУО, хоч і не довго, намагалися поширити відомості про Далекий Схід та його мешканців серед українського населення Китаю.

В українській історіографії лише стаття С. В. Капранова ${ }^{1}$ [Капранов 2011] торкнулася питань щодо відомостей про Товариство українських орієнталістів. Частково про ТУО згадав у своєму невеликому нарисі О. Пріцак для “Енциклопедії українознавства" [Пріцак 1996]. У своїй публікації ми спиратимемося на віднайдений нами збірник 1936 року “Далекий Схід” [Далекий Схід 1936], а також на роботи Івана Світа [Світ 1953; Світ 1976], де частково міститься інформація щодо цієї тематики. Основним завданням для нас буде: а) встановити роки діяльності Товариства українських орієнталістів; б) з'ясувати кількісний склад ТУО та його обов'язки; в) перелічити всі роботи ТУО, де згадано китаєзнавчі студії. Тематично публікація буде поділена на два блоки: 1) Збірник “Далекий Схід” 1936 року; 2) Звідомлення про працю Української Національної Колонії в Маньчжу-Ді-Го 1937 року. Цим і обумовлена структура нашої роботи.

\section{Збірник “Далекий Схід” 1936 року}

У 1934 році Маньчжоу-го була перетворена у Велику Маньчжурську імперію, тобто відбулася остаточна легітимізація політично-правового статусу маріонеткової держави ${ }^{2}$. Головну роль у політиці новоствореної держави відігравала Японська імперія, яка прихильно поставилася до українського населення Китаю [Young 1998, 3-21]. Це в першу чергу було пов'язано з офіційною ідеологією Маньчжурської держави: надання широких національних прав та перетворення Маньчжоу-го в багатонаціональну державуз

Товариство українських орієнталістів було засноване на початку 1936 року при Українській Національній Колонії в м. Харбіні. Такі відомості випливають із статуту ТУО, який подано в збірнику “Далекий Схід” за 1936 рік4. "При Раді Української Національної Колонії в Харбіні засновано Товариство українських орієнталістів, яке бажаючи бути посередником між народами

\footnotetext{
${ }^{1}$ Автор висловлює щиру подяку С. В. Капранову за цінні поради під час підготовки цієї публікації.

231931 року розпочалося військове вторгнення Японії до Маньчжурії, яке завершилося окупацією та проголошенням у 1932 році незалежної (фактично - маріонеткової) Маньчжурської держави (кит. Маньчжсу-го 滿洲國, япон. Маншю-коку 満州国). У 1934 році вона була проголошена конституційною монархією на чолі з останнім імператором династії Цін - Пу I (溥儀, 1906-1967) і перейменована на Велику Маньчжурську імперію (大滿洲帝國, кит. Да Маньчжоу діго, 大満州帝国япон. Дай Маншю тейкоку).

3 民族協和 Міньизу сехе.

${ }^{4}$ На титульній сторінці члени ТУО також подали назву збірника в ієрогліфічному написанні - 遠東雜誌 Юаньдун цззачжі.
} 
Сходу та Українською Нацією, ставить собі за мету: а) Студіювання мов, культури та економіки народів Сходу, зокрема народів Маньчжу-Ді-Го, Ніппон ${ }^{5}$ i $\mathrm{Xiн}^{6}$. б) Знайомити народи Сходу з Українською Нацією та ії культурою шляхом вміщення належних статей в пресі, журналах, виданням книг та брошур на східних мовах про Україну, влаштуванням лекцій і т. д. Управа Товариства закликає всіх українців, українські організації й видавництва ввійти в контакт з Управою Товариства для виконання спільними силами поставлених Товариством завдань", - зазначено в збірнику. Далі подана адреса, за якою можна звертатися для співпраці: “Вулиця Новоторгова 9, м. Харбін”. Головним в Управі ТУО був Федір Федотович Даниленко [Далекий Схід 1936, 1-2].

Даниленко Федір Федотович народився 7 липня 1875 р. в с. Дубовий Гай Прилуцького повіту Полтавської губернії. Відомий сходознавець, китаєзнавець, письменник та український громадський діяч на Далекому Сході. Проходив військову службу в 1897-1901 роках у Хабаровську. Учасник російськояпонської війни 1904-1905 років. 31907 року навчався на китайсько-маньчжурському відділенні Східного інституту у Владивостоці, який закінчив у 1911 році [Пріцак 1996, 1876]. 31918 року працював у Харбіні перекладачем 3 англійської мови в Християнському союзі молодих людей, а згодом у паспортному відділі уряду генерала Д. Хорвата. У 1925 році став одним з ініціаторів створення Інституту орієнтальних та комерційних наук, в якому в 19251940-х роках викладав англійську мову та курси "Історія матеріальної та духовної культури Сходу”, “Історія китайської літератури та громадської думки”, а згодом - в Інституті Св. Володимира [Хасамутдинов 2013, 172-173]. Публікувався в часописі "Вестник Азии” (Харбін). Зокрема у 1922 році в 48 номері було опубліковано дві його статті Ф. Даниленка "Чжан Чень перевод с китайского" i “Тигр в городе” [Даниленко 1922, 63-70; Даниленко 1922a, 68-70]. У 51 номері за 1923 рік вийшла стаття "К вопросу о развитии производительных сил Китая" [Даниленко 1923, 351-354]. У 1919 році був обраний членом Товариства російських орієнталістів у Харбіні, а згодом його секретарем та бібліотекарем. Виступав із лекціями, присвяченими китайській літературі та індійській філософії [Хисамутдинов].

На початку 1933 року науковець заснував Релігійно-філософську спілку при Українській Раді Громадських Уповноважених, яка ставила на меті вивчення індійської філософії, та одним із перших започаткував індологічні студії в Харбіні [Косинова]. У грудні 1933 року був обраний головою Ради щойно створеної Української Національної Громади, однак відмовився від цієї посади 27 лютого 1934 року на знак протесту проти політики голови Управи УНГ В. Кулябко-Корецького, залишаючись членом Управи Громади. У Державному архіві Хабаровського краю збереглася особова справа Ф. Даниленка, в якій записано, що він був прихильником українсько-російського співробітництва. Один із провідних діячів Української Національної Колонії в Харбіні, де в 1939 році був обраний членом Правління УНК, а в квітні 1940 року призначений керівником культурно-освітнього відділу УНК, член Ради Старшин УНК [Cipko 1992]. У 1942-1944 роках був працівником 2-го відділу Японської військової місії з пропаганди серед українців. Вчений брав участь у підготовці "Українсько-японського словника", який був виданий у Харбіні в 1944 році

5 日本 - самоназва Японії.

${ }^{6}$ Хінський - китайський. У 1920-30-ті роки назва “Хіна” для Китаю використовувалася також у радянській Україні. 
[Чорномаз 2011, 79-80]. Відомий далекосхідний письменник, автор белетристичних творів російською мовою. Літературною діяльністю почав займатися ще після закінчення Східного інституту. В його творах змальоване життя Зеленого Клину початку XX століття, історія Маньчжурії, Китаю, жорстокість революційної боротьби на Амурщині. Заарештований 3 жовтня 1945 року, а 4 грудня 1946 року засуджений до 10 років таборів. Відбував покарання в таборі під Тайшетом (Іркутська обл.) разом із В. Одинцем. Звільнений у 1955 році, помер у Тихонівському будинку інвалідів у Караганді (Казахстан) [Черномаз 2009, 508-509].

Відомо, що Борис Воблий був призначений секретарем 4 липня 1936 року на установчих зборах Товариства українських орієнталістів при Раді УНК [Черномаз 2017, 110]. Воблий Борис Іванович народився 2 серпня 1883 року в с. Великі Бучки Костянтиноградського повіту Полтавської губернії. Відомий перекладач, японознавець та український громадський діяч на Далекому Сході. У 1898-1904 роках навчався у Полтавській духовній семінарії, де познайомився із Симоном Петлюрою. Після закінчення духовної семінарії, вирушив у паломництво до Свято-Миколаївської церкви на ст. Погранична на кордоні Маньчжурії та Приморщини. Протягом 1906-1910 років навчався на японському відділені Східного інституту. У 1907-1909 роках став першим секретарем української організації Зеленого Клину - Владивостоцької студентської Української громади. Після закінчення інституту змінив велику кількість адміністративних посад. У 1917-1918 роках був польовим контролером на Румунському фронті. У 1918 році призначений уповноваженим представником українського уряду в Японії. Згодом працював у міністерстві продовольства в Токіо як довірена особа генерала О. Колчака (1874-1920) [Черномаз 2009, 500-501].

Після революційних подій Б. Воблий залишився працювати в Хокадате в промисловій фірмі “Нічіро” радником та перекладачем. У 1924 році запрошений японським Міністерством народної освіти працювати викладачем російської мови в комерційному училищі в м. Цуруга, де пропрацював 10 років. Тривалий час проживав у м. Кобе, де займався комерційною діяльністю. У 1935 році переїхав до Маньчжурії, де працював в управлінні КСЗ перекладачем 3 японської мови в Хамінському лісопромисловому товаристві. Викладав японську мову на сходознавчому факультеті Інституту св. Володимира в Харбіні. Через деякий час став активним членом УНК [Черномаз 2017, 110-111]. Переїхавши у Шанхай, працював у французькій фірмі. Від 8 травня 1938 року заступник голови Шанхайської Української Громади. Один з організаторів та голова Українського Емігрантського Комітету в Шанхаї у 1939-1941 роках. Через посередництво Б. Воблого перед японськими урядовцями, українські представники дістали змогу отримати національне посвідчення замість російського. Навесні 1942 року обраний членом ревізійної комісії УЕК. Відредагував книжку про Україну, яка вийшла японською мовою у Харбіні 1939 року. 1946 року покинув територію Китаю, оселившись у США. Від 1951 року проживав у Нью-Йорку. Помер у Вашингтоні [Чорномаз 2011, 58].

Розділ під назвою “Від редакції” окреслив важливість розуміння тогочасних подій, які відбувалися на Далекому Сході, та культурно-політичного взаємовпливу українського та азійських народів. Також редакція зробила акцент на браку матеріалів, котрі б дозволили якомога повніше описати культуру, історію, філософію народів Далекого Сходу, і основним своїм обов'язком 
вбачає заповнення цієї лакуни. У наступному розділі були вміщені пояснення для читача про всі тонкощі східної поезії та їі переклад, тим самим пояснюючи, що ці переклади максимально передають зміст, іноді нехтуючи розміром чи формою [Далекий Схід 1936, 3-8]. Сторінку китайської поезії в збірнику відкрили поети династії Тан (唐朝, Тан чао, 618-907) Чжан Цзюлін ${ }^{7}$ (張九齡, 678-740) з віршем "Місячні химери” та Ван Вей8 (王維, 699-759) 3 твором “Земляк”. Модерний поет Ху Пін представлений поезією “Ти весна моєї долі”. Після поезії подана інформація, що переклад здійснив М. Б. На нашу думку, це Дмитро Барченко, активний член Товариства українських орієнталістів [Барченко 1936, 7-9].

Барченко Дмитро (?, м. Київ - ?, Сіньцзін). У 1920-х роках - на еміграції в Польщі, згодом проживав на території Волині. У цей період, за деякими відомостями, видавав себе за лікаря, однак у статтях газети "Свобода" його дії були піддані нищівній критиці [В справі рецензії на Енциклопедію українознавства 1956, 3-4]. Зокрема зазначалося, що М. Барченко був лише фельдшером, привласнивши документи загиблого у війні лікаря. Згодом із ним були пов'язані події на Волині щодо викрадення грошової валюти [У справі Дмитра Барченка 1956, 3-4]. У 1931 році приїхав до Харбіна, де працював лікарем і став одним із провідних діячів українського громадського життя. Співпрацював в українських газетах "Маньчжурський вісник” (Харбін, 1932) та “Український голос на Далекому Сході” (Шанхай, 1941-1944). У другій половині 1930-х років переїхав до Сіньцзіна - столиці Маньчжурії, де мав лікарську практику. Помер там же під час Другої світової війни [Чорномаз 2003].

Також у збірнику подано переклад твору письменника часів династії Цін (清朝 Цін Чао, 1636-1912) Пу Сунліна (蒲松齡, 1640-1715) “Лянь-Сянь", який входить у збірку “Оповідання Ляо Чжая про надзвичайне” (聊齋誌異 Ляо Чжай чжі $i)^{10}$. Як зазначив сам Ф. Даниленко, на 1936 рік 146 оповідань було перекладено професором Кембриджського університету Гербертом Джайлсоном (1845-1935) під назвою "Strange stories from a Chinese studio". У творі розповідається про головного героя на ім'я Сан та його любов до двох героїнь: одна була добрим духом, а друга злим, яка була здатна перевтілюватися у лисицю ${ }^{11}$. Також Ф. Даниленко подав тлумачення твору та пояснення категоріальних філософських термінів [Даниленко 1936, 18-29]. Дмитро Барченко переклав старе маньчжурське оповідання “Справедливий I”, де описана

\footnotetext{
${ }^{7}$ Відомий поет, загальна спадщина якого складає 20 цзюаней. П’ять із них увійшли до збірки “Триста танських поем” (唐詩三百首 Танші саньбай шоу).

${ }^{8}$ Буддійське ім'я Мо изе 摩詰. Відомий також як живописець, каліграф, музикант. 29 поем якого теж увійшли до збірки “Триста поем епохи Тан”. Український переклад поезій Ван Вея зробив Геннадій Турков, видавши їх у 1987 році у видавництві “Дніпро".

9 蓮香.

${ }^{10}$ Всього у збірці 431 оповідання. Український переклад новел Пу Сунліна здійснив Іван Чирко під назвою "Ченці-чудотворці“" у видавництві “Дніпро“" 1980 року, проте твору “Лянь-Сянь” у цій збірці немає. Переклад цього оповідання зробив В. Алексєєв ще в 1920 році під назвою “Чародейка Ляньсян”, воно увійшло в збірку "Лисьи чары".

11 狐猺精 Хулі-изін - у китайській традиційній міфології чарівна лисиця, яка може бути як добрим духом, так і злим. Використовується як метафора в значенні “спокусниця”.
} 
історія легендарного китайського імператора, котрий разом із своїм радником на ім'я I з держави Чосон (Корейська імперія, яка існувала впродовж 13921897 років), допомагав вирішувати найважливіші державні питання, однак невдовзі справедливий I помер, заради спасіння підступної дружини імператора [Справедливий I 1936, 29-34]. У розділі збірника під назвою “Богиня місяця та місячний зайчик" розповідається про вплив буддизму на релігійносвітоглядні міфи Китаю, зокрема про можливість побачити зайця (月兔, юе $m y)$ на місяці, який в ступі розтирає порошок життя [Богиня місяця та місячний зайчик 1936, 34-35].

П'єса “Богиня місяця” Лі Жуйтана, вміщена у цей збірник, була передруком шостого номеру журналу "The China Journal of Science and Arts" за 1926 рік ${ }^{12}$. Події в творі відбуваються в період Хань (漢朝, Хань чао, 206 до н. е. 220 н. е), десь у пустелі, всередині печери. У творі головними персонажами $є$ героїня Чан E (嫦娥) та іiі чоловік Хоу I (後羿), разом із місячним зайцем, який у ступі розтирає чарівні трави, що дарують вічне життя смертній людині. Протягом усієї п’єси Хоу I читає книжку Дао де цзін (道德經, Книга про шлях). У кінці п’єси Чан Е перетворюється на богиню місяця, що повинна освітлювати шлях усім людям [Жуйтан 1936, 35-40]. Усі вищезазначені твори були вперше в сходознавчій науці перекладені українською мовою.

Василь Одинець у своїй статті “Хіни чи Китай” подав історію та етимологію назв “Серединної держави” (中國). Зокрема, він пише, що в основному всі назви походили від правлячої династії. Також автор наводить назви: тянь ся (天夏), хуа го (華國), хуа ся (華夏). За часів династії Чжоу (周朝, 1046 до н. е. - 256 до н. е.) поширилася назва Чжун го - серединна держава, а в часи республіки - чжун-хуа мін го (中華民國). Слова Чіна (санскр. चीन) та Махачіна (санскр. महाचीन) були поширенні на півострові Індостан, а згодом поширилися і на Єгипет. Птолемей у “Географії” теж згадував китайську державу під назвою Sina. Козьма Індикоплав у “Християнській топографіï” згадав народ Чімтіча. Науковець доводить, що назва "Китай” пішла від назви кі$\partial a b^{13}$, себто від монголо-тонгутського племені. В. Одинець також зробив спробу пояснити, чому в Україні поширилася дві назви - як Хіни, так і Китай [Одинець 1936а, 60-63] $]^{14}$.

Василь Одинець народився наприкінці XIX - на початку XX століття в Iркутську (точну дату встановити поки що неможливо через відсутність джерельної бази), а в 1922 році з батьками переїхав до Харбіна. Вищу освіту здобув в Інституті орієнтальних та комерційних наук у Харбіні за фахом китайська мова та література. Згодом залишився викладачем у цьому ж навчальному закладі. Окрім цього, брав активну участь в українському національно-культурному житті на території Китаю. Був активним членом Товариство українських орієнталістів у Харбіні, де читав лекції і публікував свої

\footnotetext{
12 Виходив з 1923 року по 1941 рік.

${ }^{13}$ Кідані 契丹 - кочові монгольські племена, що населяли територію від Маньчжурії до Середньої Азії в IV-XIII ст. Створили власну державу Ляо (遼朝 Ляо Чао, $907-$ $1125)$, яка була знищена чжурчженями.

14 Також у кінці своєї статті автор наводить список використаної літератури: a) Élisée Reclus “L’Homme et la Terre”, Paris, 1905-1908; б) S. Couling “The Encyclopedia Sinica", Shanghai, 1917; в) П. Шкуркин "Учебник востоковедения для средних учебных заведений (III ступени)”, Харбин, 1927; г) “Энциклопедический словарь Брокгауза и Ефрона", Санкт-Петербург, 1890-1907.
} 
роботи, присвячені історії, літературі та культурі Китаю. На початку 1940-х років переїхав у м. Сіньцзінь, де працював у Міністерстві закордонних справ [Світ 1953, 2-3]. Після того, як радянські війська зайняли територію Маньчжурії, був репресований і перебував на засланні в Караганді. У часи хрущовської “відлиги” підпав під реабілітацію і пов'язав своє подальше життя 3 економічною діяльністю, залишивши сходознавство як “буржуазну науку”. Помер у 1972 році [Світ 1976, 2-3]. В іншій своїй роботі "Сучасне сходознавство” В. Одинець окреслив біографію таких відомих китаїстів, як Ф. Даниленко, I. Користовець ${ }^{15}$ та японістів, як Б. Воблий та О. Галич ${ }^{16}$. Науковець у своїй роботі пояснив сам термін "сходознавство", його цілі та навів головні центри орієнталістики в різних кутках світу, від Радянської України і до сходознавства в Маньчжоу-го [Одинець 1936, 63-68].

\section{Звідомлення про працю Української Національної Колонії в Маньчжу-Ді-Го 1937 року $^{17}$}

Опубліковане "Звідомлення про працю Української Національної Колонії в Маньчжу-Ді-Го" в друкарні “Рекорд” 1937 року стало останнім джерелом, де згадується ТУО. Книга налічує 84 сторінки і є своєрідним звітом діяльності УНК. Скоріше за все, як і “Збірник”, “Звідомлення” було неперіодичним. Наприкінці книжки розташований список доповіді членів Товариства українських орієнталістів з грудня 1936 по березень 1937 років. Всього було прочитано 8 лекцій, нам доступні тези лише сімох. Доповідь Т. Гордєєва "Умови сільського господарства в Маньчжурії” нам відома лише за назвою [Звідомлення... 1937, 26].

Тарас Петрович Гордєєв - відомий педагог, ботанік, агроном, грунтознавець, письменник та поет. Народився 30 липня 1875 року в Санкт-Петербурзі. 31879 року жив у Харкові. Після закінчення Сумського реального училища в 1894 році вступив до Новоолександрівського інституту сільського господарства та лісництва в Пулавах, де в той час працювали одні з найкращих спеціалістів. Протягом 1898-1900 років знову жив у Харкові, працюючи в організації “Грамотність". У 1900-1907 роках проходив службу в Саратовському губернському земстві. У 1910-х роках вирушив у мандри Японією і Далеким Сходом. Емігрував у Китай у 1922 році, де працював в освітньому відділі КСЗ [Левитский]. Член організації з вивчення Маньчжурського краю (1922-1925). У 1925 році був звільнений з освітнього відділу КС3 за “безпідданство". Викладав у реальному училищі Гуанхуа, гімназії ім. Ф. Достоєвського, Олексіївському реальному училищі та Російському домі. Учасник першого польового походу Маньчжурської експедиції Н. Реріха в 1934 році. Працівник музею

${ }^{15}$ Користовець Іван Якович (1862-1933) - відомий дипломат та сходознавець. Посол Російської імперії в Пекіні. Був уповноваженим від Української Держави для переговорів із представниками Антанти в Яссах.

16 Галич Олексій Іванович - сходознавець. Закінчив Східний інститут у Владивостоці. Деякий час мешкав у Харбіні та Таньцзіні. Викладав курси з японської мови в Інституті орієнтальних та комерційних наук у Харбіні. Основною сферою зацікавлення були японо-китайські соціально-економічні відносини.

${ }^{17}$ Ми в своїй публікації не будемо акцентувати значну увагу на це джерело, так як детально про це вже написав С. Капранов. Дивитися в Капранов С. Діяльність Товариства українських орієнталістів у Харбіні (1936-1937рр.). Східний світ. Київ, 2011. № 3. С. 74-85. 
Хейлунцзянської провінції з 1949 року, однак вже в 1962 році залишив службу і переїхав до Бельгії, де і помер в 1967 році [Рерих 2015, 234]. Нам через брак джерельної бази невідомо, чи співпраця Товариства українських орієнталістів і Т. Гордєєва була тривалою і чи вона обмежувалася тільки його поодинокими лекціями.

28 січня 1937 року відбулася доповідь Василя Одинця на тему “Ван-Дао” в Українському Національному Домі ${ }^{18}$. У цій роботі науковець акцентував увагу на "Шлях правителя" та притаманні йому риси протягом усієї історії Китаю. Також автор вводить у своїй роботі важливі категоріальні поняття конфуціанської моралі. На думку науковця, ідеальним прототипом правителя можна назвати Нурхаці (努爾哈赤, 1559-1626) [Звідомлення... 1937, 78-81]. Валентина Коротенко виступила 3 доповіддю “Любов у хінців” 3 грудня 1936 року, де оглядово розглянула поняття “любові” всебічно, акцентувавши, що основним його проявом є милосердя [Звідомлення... 1937, 81].

Коротенко-Корда Валентина Григорівна народилася 2 лютого 1912 року в м. Хайлар. Українська молодіжна діячка в Харбіні. Дружина Романа КордиФедорова. Закінчила вище початкове училище в Хайларі, залізничну гімназію в 1930 році та Інститут Св. Володимира в Харбіні 1935 року. За фахом - синолог. Активістка Української Далекосхідньої Січі. ІІЇ праці, на заклик жіночого руху, були надруковані в “Далекосхідному націоналістові” ${ }^{19}$ в Харбіні 1937 року. Керівник жіночого гуртка при УНК протягом 1938-1939 років [Чорномаз]. Активний член ТУО.

В. Одинець 10 грудня 1936 року виголосив доповідь на тему “Культ предків у хінців”, де було висвітлено глибоку пошану китайців до своїх предків, згідно 3 конфуціанськими нормами моралі [Звідомлення... 1937, 81]. Федір Даниленко 17 грудня 1936 року зробив доповідь на тему “Богиня милосердя”, себто розповів про бодгісаттву Авалокітешвару, втілення безмежного милосердя усіх будд [Звідомлення... 1937, 81-82].

У наступній своїй доповіді "Конфуцій та його наука" 4 лютого 1937 року Федір Федотович розповів про легендарного філософа Китаю, а також про його подальший вплив на історію людства. Василь Аксентійович Одинець 18 лютого 1937 року прочитав доповідь на тему “Піонери українського сходознавства”, акцентуючи на довготривалих відносинах України 3 державами Сходу та на практичній потребі сходознавців, а також про неоцінний вклад українських орієнталістів у російську науку [Капранов 2011, 74-78]. Інша доповідь науковця на тему "Пізнаймо Схід” відбулася 4 березня 1937 року [Звідомлення... 1937, 82], де автор пояснив реальну перспективу і потребу у всебічному вивченні Сходу, а Далекого Сходу позачергово для українських науковців.

\section{Висновки}

Проведене дослідження показує, що Товариство українських орієнталістів було засноване на початку 1936 року. Його активними членами були:

18 王道 - одне 3 важливих понять китайської суспільно-політичної філософії, що означає конфуціанський ідеал правління. Протилежним йому є право сили 強權 ияянцюань, яке відповідає шляху тирана 霸道 Ба дао.

${ }^{19}$ Неперіодичне видання українських націоналістів у Харбіні. В основному його зміст був присвячений питанням міжнародних відносин на Далекому Сході та активізації українського політичного руху на території Китаю. 
Федір Даниленко (президент), Дмитро Барченко, Борис Воблий (секретар), Василь Одинець, Валентина Корда-Коротенко. ТУО стало неформальною організацією, що об'єднала навколо себе науковців, які цікавилися історією, філософією, мовою та літературою народів Далекого Сходу. Продуктом їхньої нетривалої діяльності став збірник “Далекий Схід” (遠東雜誌) 1936 року, який засвідчив готовність українських сходознавців до активної наукової праці та розуміння важливості щодо поширення відомостей про Китай та Японію серед широкого кола населення. На відміну від сходознавства в УРСР, де домінувала соціально-політична й економічна проблематика, українські сходознавці на території Китаю цікавилися філософськими, релігієзнавчими та культурологічними питаннями. Опубліковане “Звідомлення про працю Української Національної Колонії в Маньчжу-Ді-Го” в друкарні “Рекорд” 1937 року стало останнім джерелом, де згадується назва ТУО. Фактично за 1938 рік ми не знайшли жодних відомостей про діяльність Товариства українських орієнталістів. Можливо, це було пов'язано з фінансовим становищем організації та війною, яка відбувалася на Далекому Сході, або через зміну політичної орієнтації японської влади у Харбіні. Тим не менш, поодинокі праці українських сходознавців траплялися нам у періодичних виданнях, однак вже без зазначення членства ТУО. Особливо цінними для української науки $є$ перекладені твори з китайської мови, що досі не мають аналогів у вітчизняній китаїстиці. Можна лише сподіватися, що в майбутньому вдасться знайти джерела, які дозволять пролити світло на ці важливі сторінки вітчизняної орієнталістики.

\section{ЛІТЕРАТУРА}

Барченко Д. Китайська поезія // Далекий Схід. Харбін, 1936.

Богиня місяця та місячний зайчик // Далекий Схід. Харбін, 1936.

В справі рецензії на Енциклопедію українознавства // Свобода. 27 листопада. Ч. 227. Джерсі ситі, 1956.

Далекий Схід: збірник, присвячений справам українського Далекого Сходу. Харбін: видання Ради Української Національної Колонії у МаньчжуДі-Го, 1936.

Даниленко Ф. Тигр в городе // Вестник Азии. Харбин, 1922, № 48.

Даниленко Ф. Чжань Чэнь // Вестник Азии. Харбин, 1922a, № 48.

Даниленко Ф. К вопросу о развитии производительных сил Китая // Вестник Азии. Харбин, 1923, № 51.

Даниленко Ф. Лянь-Сянь // Далекий Схід. Харбін, 1936.

Жуйтан Л. Богиня місяця // Далекий Схід. Харбін, 1936.

Звідомлення про працю Української Національної Колонії в МаньчжуДі-Го. Харбін, 1937.

Капранов С. Діяльність Товариства українських орієнталістів у Харбіні (1936-1937 рр.) // Східний світ. Київ, 2011, № 3.

Косинова О. Востоковедческая и краеведческая подготовка в учебных заведениях российского зарубежья в Китае. URL: http://www.zpu-journal.ru/ e-zpu/2008/2/Kosinova_training/ (дата звернення - 22.11.2018).

Левитский В. Гордеев Тарас Петрович. URL: http://myharbin.name/personalii/182-gordeev-taras-petrovich (дата звернення - 25.05.2019).

Оглезнева Е. Славянское языковое присутствие в Китае первой половины XX в. (на материале Харбина - центра русского восточного зарубежья). URL: https://cyberleninka.ru/article/v/slavyanskoe-yazykovoe-prisutstvie-v-kitae- 
pervoy-poloviny-hh-v-na-materiale-harbina-tsentra-russkogo-vostochnogozarubezhya (дата звернення - 25.05.2019).

Одинець B. Сучасне сходознавство // Далекий Схід. Харбін, 1936.

Одинець В. Хіни чи Китай // Далекий Схід. Харбін, $1936 a$.

Пріщак O. Орієнталістика // Енциклопедія українознавства. Т. 5. Львів, 1996.

Рерих Н. Дневник Маньчжурской экспедиции (1934-1935). Москва, 2015.

Свim I. Доля українських орієнталістів // Свобода. 14 лютого. Ч. 29. Джерсі ситі, 1976.

Cвim I. Україна в азійських мовах // Свобода. 14 серпня. Ч. 172. Джерсі ситі, 1953.

Справедливий І. // Далекий Схід. Харбін, 1936.

У справі Дмитра Барченка // Свобода. 27 грудня. Ч. 248. Джерсі ситі, 1956.

Хисамутдинов А. Русские волны на Пасифике: Из Росии через Китай,

Корею и Японию в Новый Свет. Пекин - Владивосток, 2013.

Хисамутдинов А. Русские етнографы-эмигранты в Маньчжурии, их труды и судьбы. URL: https://docplayer.ru/amp/29871184-Izuchaya-kitay-trudyi-sudby-russkih-emigrantov.html (дата звернення - 25.05.2019).

Черномаз $B$. Украинское Национальное Движение на Дальнем Востоке (1917-1922 гг.). Владивосток, 2009.

Чорномаз В. Дмитро Барченко // Енциклопедія сучасної України, 2003.

T. 2. URL: http://esu.com.ua/search_articles.php?id=40651 (дата звернення 13.11.2018). 2011.

Чорномаз В. Зелений Клин (Український Далекий Схід). Владивосток,

Чорномаз $B$. Сумчани в Українському національному русі на Далекому

Сході. URL: http://e-news.com.ua/print/281352.html (дата звернення - 21.11.2018).

Чорномаз В. Українці в Шанхаю. Київ, 2017.

Cipko S. Ukrainians in Manchuria // Past Imperfect, 1992, № 1.

Young L. Japan's Total Empire: Manchuria and the Culture of Wartime imperialism. University of California Press, Berkeley and Los Angeles, California, 1998.

\section{REFERENCES}

Barchenko D. (1936), “Kytays'ka poeziya”, Dalekyy Skhid, Kharbin, pp. 7-9. (In Ukrainian).

"Bohynya misyatsya ta misyachnyy zaychyk" (1936), Dalekyy Skhid, Kharbin, pp. 34-35. (In Ukrainian).

"V spravi retsenziyi na Entsyklopediyu ukrayinoznavstva" (1956), Svoboda, 27 lystopada. Ch. 227. Dzhersi syti, pp. 2-3. (In Ukrainian).

Dalekyy Skhid (1936), zbirnyk prysvyachenyy spravam ukrayins'koho Dalekoho Skhodu, Vydannya Rady Ukrayins'koyi Natsional'noyi Koloniyi u Man'chzhu-DiHo, Kharbin. (In Ukrainian).

Danilenko F. (1922), “Tigr v gorode”, Vestnik Azii, Kharbin, No. 48, pp. 68-70. (In Russian).

Danilenko F. (1922a), Chzhan' Chen', Vestnik Azii, Kharbin, No. 48, pp. 63-68. (In Russian).

Danilenko F. (1923), K voprosu o razvitii proizvoditel'nykh sil Kitaya, Vestnik Azii, Kharbin, No. 51, pp. 351-354. (In Russian). 
Danylenko F. (1936), “Lyan'-Syan'”, Dalekyy Skhid, Kharbin, pp. 18-29. (In Ukrainian).

Zhuytan L. (1936), "Bohynya misyatsya", Dalekyy Skhid, Kharbin, pp. 35-40. (In Ukrainian).

Zvidomlennya pro pratsyu Ukrayins'koyi Natsional'noyi Koloniyi v Man'chzhuDi-Ho (1937), Kharbin. (In Ukrainian).

Kapranov S. (2011), “Diyal'nist' Tovarystva ukrayins'kykh oriyentalistiv u Kharbini (1936-1937 rr.)", Skhidnyy svit, Kyiv, No. 3, pp. 74-85. (In Ukrainian).

Kosinova O., "Vostokovedcheskaya i krayevedcheskaya podgotovka v uchebnykh zavedeniyakh rossiyskogo zarubezh'ya v Kitaye", available at: http://www. zpu-journal.ru/e-zpu/2008/2/Kosinova_training/ (accessed 22 May 2019). (In Russian).

Levitskiy V., "Gordeyev Taras Petrovich", available at: http://myharbin.name/ personalii/182-gordeev-taras-petrovich (accessed 25 May 2019). (In Russian).

Oglezneva E., "Slavyanskoye yazykovoye prisutstviye v Kitaye pervoy poloviny XX v. (na materiale Kharbina - tsentra russkogo vostochnogo zarubezh'ya)", available at: https://cyberleninka.ru/article/v/slavyanskoe-yazykovoe-prisutstvie-v-kitae-pervoy-poloviny-hh-v-na-materiale-harbinatsentrarusskogovostochnogozarubezhya (accessed 25 May 2019). (In Russian).

Odynets'V. (1936), "Suchasne skhodoznavstvo", Dalekyy Skhid, Kharbin, pp. 63-68. (In Ukrainian).

Odynets'V. (1936a), "Khiny chy Kytay”, Dalekyy Skhid, Kharbin, pp. 60-63. (In Ukrainian).

Pritsak O. (1996), “Oriyentalistyka”, Entsyklopediya ukrayinoznavstva, Vol. 5, L'viv, pp. 1600-2000. (In Ukrainian).

Rerikh N. (2015), Dnevnik Man'chzhurskoy ekspeditsii (1934-1935), Mezhdunarodnyy Tsentr Rerikhov, Moskva. (In Russian).

Svit I. (1976), "Dolya ukrayins'kykh oriyentalistiv, Svoboda, 14 lyutoho, Ch. 29, Dzhersi syti, pp. 2-3. (In Ukrainian).

Svit I. (1953), "Ukrayina v aziys'kykh movakh”, Svoboda, 14 serpnya, Ch. 172, Dzhersi syti, pp. 2-3. (In Ukrainian).

Spravedlyvyy I. (1936), Dalekyy Skhid, Kharbin, pp. 29-34. (In Ukrainian).

"U spravi Dmytra Barchenka" (1956), Svoboda, 27 hrudnya, Ch. 248, Dzhersi syti, pp. 3-4. (In Ukrainian).

Khisamutdinov A. (2013), Russkiye volny na Pasifike: Iz Rosii cherez Kitay, Koreyu $i$ Yaponiyu v Novyy Svet, Pekin, Vladivostok: Rubezh. (In Russian).

Khisamutdinov A., "Russkiye etnografy-emigranty v Man'chzhurii, ikh trudy i sud'by", available at: https://docplayer.ru/amp/29871184-Izuchaya-kitay-trudy-isudby-russkih-emigrantov.html (accessed 25 May 2019). (In Russian).

Chernomaz V. (2009), Ukrainskoye Natsional'noye Dvizheniye na Dal'nem Vostoke (1917-1922 gg.), Vladivostok: Izdatel'stvo Dal'nevostochnogo universiteta. (In Russian).

Chornomaz V., "Dmytro Barchenko", available at: http://esu.com.ua/search_articles.php?id=40651 (accessed 13 May 2019). (In Ukrainian).

Chornomaz V. (2011), Zelenyy Klyn (Ukrayins'kyy Dalekyy Skhid), Vladyvostok: Vydavnytstvo Dalekoskhidnoho federal'noho universytetu. (In Ukrainian).

Chornomaz V., "Sumchany v Ukrayins'komu natsional'nomu rusi na Dalekomu Skhodi", available at: http://e-news.com.ua/print/281352.html (accessed 21 May 2019). (In Ukrainian). 
Chornomaz V. (2017), Ukrayintsi v Shankhayu, Kyiv: Znannya Ukrayiny.(In Ukrainian).

Cipko S. (1992), "Ukrainians in Manchuria", Past Imperfect, 1992, № 1, pp. 155-73.

Young L. (1998), Japan's Total Empire: Manchuria and the Culture of Wartime imperialism, University of California Press, Berkeley and Los Angeles, California.

\section{ТОВАРИСТВО УКРАЇНСЬКИХ ОРІЕНТАЛІСТІВ У ХАРБІНІ (1936-1938 рр.): КИТАЄЗНАВЧІ СТУДІЇ}

\section{P. A. Лax}

У пропонованій роботі висвітлено діяльність Товариства Українських Орієнталістів на Далекому Сході. Вперше 3'ясовано роки існування та осіб, що входили до організації. Особливий акцент зроблено на китаєзнавчих студіях товариства як невід'ємному елементові сходознавчої науки. У дослідженні представлені розвідки з історії, філософії та літератури Китаю Ф. Даниленка, В. Одинця, Д. Барченка, що досі не були предметом досліджень. Коротко подано деякі деталі з біографії українських сходознавців на Далекому Сході. Вперше проаналізований збірник ТУО під назвою “Далекий Схід” (1936).

Ключові слова: Товариство Українських Орієнталістів, китаєзнавство, українські сходознавці, українсько-китайські відносини, Харбін

\section{ОБЩЕСТВО УКРАИНСКИХ ОРИЕНТАЛИСТОВ В ХАРБИНЕ (1936-1938 ГГ.): КИТАЕВЕДЧЕСКИЕ СТУДИИ}

P. A. Лax

В предлагаемой работе отражена деятельность Общества Украинских Ориенталистов на Дальнем Востоке. Впервые установлены годы существования и лица, входившие в организацию. Особый акцент сделан на китаеведческих студиях общества как неотъемлемой части востоковедения. В исследовании представлены работы по истории, философии и литературе Китая Ф. Даниленко, В. Одинца, Д. Барченко, которые до сих пор не были предметом исследований. Коротко представлены некоторые детали из биографии украинских востоковедов на Дальнем Востоке. Впервые проанализирован сборник ОУО под названием “Дальний Восток” (1936).

Ключевые слова: Общество Украинских Ориенталистов, китаеведение, украинские востоковеды, китайско-украинские отношения, Харбин 